\title{
31. PALEOCLIMATIC RECORD OF THE PLIOCENE AT DEEP SEA DRILLING PROJECT SITES 519, 521, 522, AND 523 (CENTRAL SOUTH ATLANTIC) ${ }^{1}$
}

\author{
H. J. Weissert and J. A. McKenzie, Geologisches Institut, Eidgenössische Technische Hochschule Zürich, \\ CH-8092 Zürich, Switzerland \\ R. C. Wright, Exxon Production Research Co., Houston, Texas \\ M. Clark, Florida State University, Tallahassee, Florida ${ }^{2}$ \\ and \\ H. Oberhänsli and M. Casey, Geologisches Institut, Eidgenössische Technische Hochschule Zürich, \\ CH-8092 Zürich, Switzerland
}

\begin{abstract}
We established a composite oxygen- and carbon-isotope stratigraphy for the Pliocene in the central South Atlantic. Monospecific samples of benthic and planktonic foraminifers from pelagic sediments from DSDP Sites 519, 521, 522, and 523 were analyzed isotopically. The resulting benthic oxygen-isotope stratigraphy allowed three paleoclimatic periods in the Pliocene to be distinguished. During the early Pliocene (5.2-3.3 Ma), low-amplitude climatic changes prevailed in a world that was less glaciated than during the Pleistocene. A net increase in global ice volume is documented in a $0.5 \%$ positive shift in the average ${ }^{18} \mathrm{O}$ composition of the benthic foraminifers at 3.2 Ma. The middle Pliocene (3.3-2.5 Ma) is not only characterized by a more widespread glaciation of the Southern and Northern hemispheres but also by more drastic isotopic differences between glacial and interglacial times. A minor shift in the average ${ }^{18} \mathrm{O}$ composition of the benthic foraminifers marks the beginning of the late Pliocene-early Pleistocene climatic period (2.5-1.1 Ma). Alternating cold and warm climate is documented in both the oxygen-isotope record and in the pelagic sediments. During cold periods, sediments with a lower $\mathrm{CaCO}_{3}$ content indicate more corrosive bottom-water conditions. More negative ${ }^{13} \mathrm{C}$ signals in the benthic foraminifers from these sediments suggest that the Antarctic Bottom Water current was intensified in glacial times. The oxygen-isotope composition of the measured planktonic foraminifers suggests that the surface water in this part of the South Atlantic remained relatively warm during the growth of the Pliocene glaciers.
\end{abstract}

\section{INTRODUCTION}

The development of stable-isotope geochemistry more than $30 \mathrm{yr}$. ago provided a valuable tool for the reconstruction of glacial history in the Cenozoic world. Early documentation of glacial-interglacial cycles throughout the late Pleistocene was provided by Emiliani (1955); numerous studies done since have not only confirmed his results but have recognized the imprint of alternating glacial-interglacial periods on the sedimentary record. The Pliocene, the time of interest in the present study, is known to the paleoclimatologist as a time of expanding glaciers in the Southern and Northern hemispheres. By the late Pliocene, climatic conditions were established that were comparable to those of the Pleistocene.

In the present study we focus our attention on two main topics. First we attempt to reconstruct the oceanographic conditions in the central South Atlantic during the major global cooling in the middle Pliocene. Analysis of the ${ }^{18} \mathrm{O}$ and ${ }^{13} \mathrm{C}$ composition of benthic foraminifers yields information on physical and chemical changes in bottom water. Surface-water conditions during this major climatic change are recorded in the isotopic composition of planktonic foraminifers. Second, we attempt to find the cause of cyclic changes in the pelagic facies

\footnotetext{
${ }^{1}$ Hsü, K. J., LaBrecque, J. L., et al., Init, Repts. DSDP, 73: Washington (U.S. Govt. Printing Office).

2 Present address: Union Oil Co. of California, Houston, Texas.
}

pattern in the upper Pliocene of Sites 522 and 523. Stable-isotope data were combined with sedimentological and micropaleontological observations to reconstruct late Pliocene paleoceanography in a part of the eastern South Atlantic.

\section{STRATIGRAPHY}

The studied sites are situated in the central South Atlantic east of the Mid-Atlantic Ridge in the Angola Basin at a latitude of 26 to $28^{\circ} \mathrm{S}$ (Fig. 1). Their depth today ranges from $3769 \mathrm{~m}$ (Site 519) to $4563 \mathrm{~m}$ (Site 523). Throughout most of the Pliocene a uniform white nannofossil ooze with a $\mathrm{CaCO}_{3}$ content of more than $90 \%$ was deposited in the area of study. At Site 519, which is situated on the flank of a morphologic high, the pelagic sequence is frequently interrupted by redeposited carbonate ooze. These redeposited sediments, which are regarded as noise in the uniform record, were formed by subaqueous gravity flows, by low-density turbidity currents, and by bottom currents. At all the other sites studied the Pliocene sequence seems to be generally unaffected by physical sediment-redistribution processes. However, bioturbation features give evidence of widespread bottom fauna activity throughout the Pliocene. Benthic mixing sets certain limits on the resolution of the isotope record (Ruddiman and Glover, 1972). However, a resolution of low-frequency oceanographic and climatic changes on the order of $10^{4} \mathrm{yr}$. is reasonable at these sites. If we consider the worst possible case (the late Pliocene of Site 522), in which the average sample 


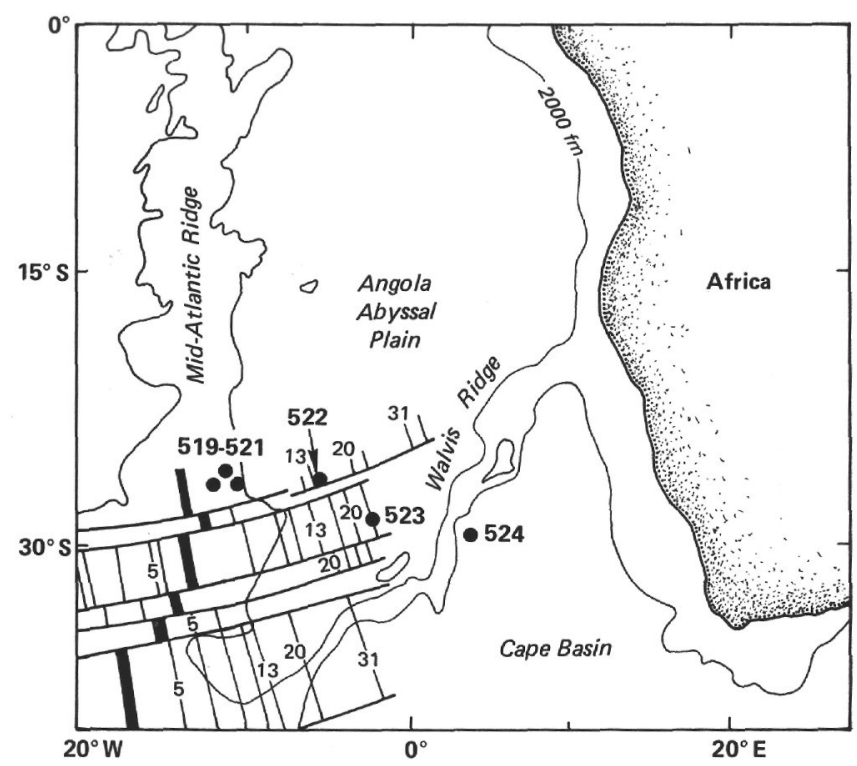

Figure 1. Location of Sites 519, 520, 521, 522, and 523. Numbers beside dots indicate drill sites, and numbers between lines indicate seafloor anomalies.

spacing is $36 \mathrm{~cm}$ and the sediment accumulation rate is $8 \mathrm{~cm} / 10^{4} \mathrm{yr}$., we should easily be able to resolve events with a frequency of $10^{4} \mathrm{yr}$. or more.

The monotonous pelagic facies picture changes in the upper Pliocene interval at Sites 522 and 523. A series of layers of dark nannofossil ooze up to $10 \mathrm{~cm}$ thick with a $\mathrm{CaCO}_{3}$ content of 60 to $70 \%$ alternates with layers of white nannofossil ooze up to $50 \mathrm{~cm}$ thick. Both the upper and lower contacts of the dark beds are strongly affected by bioturbation. Although the average sedimentation rate of the light coccolith ooze is $0.8 \mathrm{~cm} / 10^{3} \mathrm{yr}$., only $0.2 \mathrm{~cm}$ of the dark ooze were deposited in $10^{3} \mathrm{yr}$. This estimate is based on the assumption that the sedimentation rate of the clay minerals in the central South Atlantic remained constant throughout late Pliocene (Violanti et. al., 1979).

\section{OCEANOGRAPHY}

Of primary importance in our paleoceanographic study is the history of South Atlantic bottom-water conditions, which is intimately coupled with the glaciation history of the Southern and Northern hemispheres. Today, the northward-flowing Antarctic Bottom Water (AABW) current brings nutrient-rich water into the western South Atlantic (Argentine Basin and Brazil). Because of the blocking influence of the Walvis Ridge, the AABW current reaches the Angola Basin in the eastern South Atlantic only indirectly, by passing through the Romanche Fracture Zone near the equator and then by flowing southward into the Angola Basin. The influence of the AABW on the Angola Basin today is limited because of this circuitous route. However, this deep circulation pattern may not have obtained during the Pliocene. If the AABW migrated upward only a few hundred meters it could spill over the Walvis Ridge and become much more influential in the Angola Basin hydrography. Climatically controlled fluctuations in the intensity of the corrosive AABW may be recorded in the isotopes and micropaleontology.

\section{MATERIAL AND METHODS}

On board ship, 10-cc sediment samples were taken for the Pliocene paleoceanography study. The samples were washed with distilled water, and foraminifer samples were prepared for isotope analysis at Florida State University, Tallahassee; at the United States Geological Survey (USGS) in Menlo Park; and at the Eidgenössische Technische Hochschule in Zürich. The foraminifers were picked by hand from the $>180 \mu \mathrm{m}$ size fraction. The benthic species Planulina wuellerstorfi, Nuttalides umbonifera, and Oridorsalis umbonatus were chosen for information on bottom-water history. Globigerinoides sacculifer, G. conglobatus, G. ruber, and Orbulina universa provide a record of the upper water masses. In Zurich, the monospecific benthic and planktonic samples chosen for analysis were roasted in vacuo for $30 \mathrm{~min}$. at $400^{\circ} \mathrm{C}$. Organic contaminants were removed by this cleaning method. In a microline attached to a Micromass 903 mass spectrometer, the samples were reacted with $100 \% \mathrm{H}_{3} \mathrm{PO}_{4}$ at $50^{\circ} \mathrm{C}$. The samples were measured against a Carrara marble laboratory standard. The final results, corrected according to Craig (1957), are expressed in per mill deviations relative to the PDB standard. The standard deviation of the mean calculated for replicate analysis is $\pm 0.1 \%$ for $\delta^{13} \mathrm{C}$ and $\pm 0.2 \%$ for $\delta^{18} \mathrm{O}$.

The data from different planktonic and benthic species are not directly comparable because of species-specific departures from isotopic equilibrium. Among the measured benthic species, $P$. wuellerstorfi and $N$. umbonifera have an oxygen-isotope composition that is up to $1 \%$ more negative than calculated equilibrium values (Woodruff et al., 1980; and Vincent et al., 1981). Oridorsalis umbonatus precipitated its shell carbonate closer to oxygen-isotope equilibrium conditions. In terms of carbon-isotope composition, all the analyzed benthic species are depleted in the heavy ${ }^{13} \mathrm{C}$ isotope relative to equilibrium. Planulina wuellerstorfi seems to be closest to the equilibrium number, $N$. umbonifera is up to $1.5 \%$ too negative, and ${ }^{13} \mathrm{C}$ values for O. umbonatus are between 1 and $2 \%$ lighter than in $\mathrm{CaCO}_{3}$ precipitated in equilibrium with dissolved $\mathrm{CO}_{2}$ (Woodruff et al., 1980).

The planktonic species $G$. ruber has an oxygen-isotope composition that reflects average summer surface-water conditions (Deuser et al., 1981). Globigerinoides conglobatus is depleted in the heavy oxygen isotope by 0.2 to $0.5 \%$, and $G$. sacculifer seems to be close to isotopic equilibrium with surface water throughout most of the year (Deuser et al., 1981). The slightly too positive ${ }^{18} \mathrm{O}$ values measured on Orbulina universa may indicate a deeper living habitat, as suggested by Shackleton and Vincent (1978). All the analyzed planktonic species are depleted in the heavy carbon isotope (Williams et al., 1977; and Kahn and Williams, 1981).

In addition to being analyzed isotopically, the sediment samples were washed on a $63 \mu \mathrm{m}$ sieve, and the following observations were made on the portion of the residue $>125 \mu \mathrm{m}$ : (1) the proportion of benthic foraminifer tests relative to the entire foraminiferal population, (2) the proportion of planktonic foraminiferal fragments relative to fragments and whole tests, and (3) the proportional contribution of $N$. umbonifera to the benthic assemblage. The first two of these parameters increase with the degree of carbonate dissolution. The last parameter appears to be positively correlated with the degree of carbonate undersaturation in the water column today (Bremer and Lohmann, 1982).

\section{RESULTS}

The results are tabulated in Table 1 and plotted in Figures 2 to 6 .

The composite benthic oxygen-isotope stratigraphy of the studied sites allows the distinction of three paleoclimatic periods in the Pliocene (Fig. 6).

\section{Early Pliocene (5.2-3.3 Ma)}

In the oldest part of the Pliocene, the oxygen-isotope curve of all the analyzed benthic foraminifers is remarkably constant. An average of $\delta^{18} \mathrm{O}=+2.6 \%$ o $\pm .2 \%$ was 
Table 1A. Oxygen- and carbon-isotope data (\%) for Hole 519.

\begin{tabular}{|c|c|c|c|c|c|c|c|c|c|c|c|}
\hline \multirow{2}{*}{$\begin{array}{l}\text { Core-Section } \\
\text { (interval in cm) }\end{array}$} & \multirow{2}{*}{$\begin{array}{l}\text { Sub-bottom } \\
\text { depth } \\
\text { (m) }\end{array}$} & \multicolumn{2}{|c|}{$\begin{array}{c}\text { Planulina } \\
\text { wuellerstorf } i\end{array}$} & \multicolumn{2}{|c|}{$\begin{array}{l}\text { Nuttalides } \\
\text { umbonifera }\end{array}$} & \multicolumn{2}{|c|}{$\begin{array}{c}\text { Globoquadrina } \\
\text { altispira }\end{array}$} & \multicolumn{2}{|c|}{$\begin{array}{c}\text { Globigerinoides } \\
\text { sacculifer }\end{array}$} & \multicolumn{2}{|c|}{$\begin{array}{l}\text { Orbulina } \\
\text { universa }\end{array}$} \\
\hline & & $\delta^{18} \mathrm{O}$ & $\delta^{13} \mathrm{C}$ & $\delta^{18} \mathrm{O}$ & $\overline{\delta^{13} \mathrm{C}}$ & $\delta^{18} \mathrm{O}$ & $\delta^{13} \mathrm{C}$ & $\delta^{18} \mathrm{O}$ & $\delta^{13} \mathrm{C}$ & $\delta^{18} \mathrm{O}$ & $\delta^{13} \mathrm{C}$ \\
\hline $9-1,35-37$ & 31.65 & +3.11 & +0.79 & +3.49 & +0.86 & & & & & & \\
\hline $9-2,35-37$ & 33.15 & & & & & & & -0.12 & +1.99 & & \\
\hline $10-2,50-52$ & 37.30 & +2.53 & +1.12 & & & & & +0.29 & +2.39 & & \\
\hline $12-3,38-40$ & 47.48 & +3.42 & +0.40 & & & & & +0.74 & +1.46 & & \\
\hline $13-2,100-102$ & 51.00 & & & +2.62 & +0.85 & & & -0.10 & +1.95 & & \\
\hline $14-2,80-82$ & 56.20 & & & & & & & +0.89 & +2.40 & & \\
\hline $15-2,50-52$ & 59.30 & & & & & & & +0.61 & +2.01 & & \\
\hline $16-2,49-51$ & 63.69 & +2.61 & +1.21 & +2.63 & +0.92 & & & +0.27 & +2.38 & & \\
\hline $16-2,105-107$ & 64.25 & +2.73 & +1.05 & +2.78 & +0.78 & +1.19 & +1.49 & +0.30 & +2.01 & & \\
\hline $16-3,49-51$ & 65.19 & +2.48 & +0.68 & +3.08 & +0.59 & +0.79 & +1.55 & +0.25 & +1.85 & & \\
\hline $18-1,100-102$ & 71.50 & & & +2.64 & +0.87 & +1.08 & +1.61 & & & & \\
\hline $20-2,70-72$ & 81.50 & & & +2.68 & +0.80 & & & +0.50 & +2.37 & & \\
\hline $22-2,63-65$ & 90.23 & +2.21 & +0.84 & & & +0.81 & +1.61 & +0.56 & +2.34 & & \\
\hline $23-2,115-117$ & 95.15 & +1.92 & +0.60 & +1.80 & +0.42 & +0.65 & +1.56 & +0.15 & +2.41 & & \\
\hline $24-1,34-36$ & 97.25 & +2.01 & +0.61 & & & & & & & & \\
\hline $24-1,55-57$ & 97.45 & +2.17 & +0.82 & +2.27 & +0.69 & & & & & & \\
\hline $24-2,130-132$ & 99.71 & +2.34 & +1.16 & & & & & & & & \\
\hline $24-3,113-115$ & 101.00 & & & +2.54 & +0.61 & +0.60 & +2.13 & & & & \\
\hline $25-1,14-16$ & 101.40 & +2.30 & +1.22 & & & & & & & +0.60 & +2.26 \\
\hline $26-1,38-40$ & 106.20 & & & & & & & & & +0.76 & +2.19 \\
\hline $27-1,9-11$ & 110.20 & +2.48 & +0.90 & & & & & & & & \\
\hline $27-1,24-26$ & 110.40 & +2.59 & +1.15 & & & & & & & +1.17 & +2.15 \\
\hline $27-1,65-67$ & 110.80 & +2.59 & +1.39 & & & & & & & & \\
\hline $27-2,88-90$ & 112.50 & +2.52 & +1.04 & & & & & & & +0.74 & +2.02 \\
\hline
\end{tabular}

Table 1B. Oxygen- and carbon-isotope data (\%) for Hole 521.

\begin{tabular}{|c|c|c|c|c|c|c|c|c|c|}
\hline \multirow{2}{*}{$\begin{array}{l}\text { Core-Section } \\
\text { (interval in cm) }\end{array}$} & \multirow{2}{*}{$\begin{array}{l}\text { Sub-bottom } \\
\text { depth } \\
\text { (m) }\end{array}$} & \multicolumn{2}{|c|}{$\begin{array}{c}\text { Planulina } \\
\text { wuellerstorfi }\end{array}$} & \multicolumn{2}{|c|}{$\begin{array}{c}\text { Nuttalides } \\
\text { umbonifera }\end{array}$} & \multicolumn{2}{|c|}{$\begin{array}{l}\text { Oridorsalis } \\
\text { umbonatus }\end{array}$} & \multicolumn{2}{|c|}{$\begin{array}{c}\text { Globigerinoides } \\
\text { sacculifer }\end{array}$} \\
\hline & & $\delta^{18} \mathrm{O}$ & $\delta^{13} \mathrm{C}$ & $\delta^{18} \mathrm{O}$ & $\delta^{13} \mathrm{C}$ & $\delta^{18} \mathrm{O}$ & $i^{13} \mathrm{C}$ & $\delta^{18} \mathrm{O}$ & ${ }^{13} \mathrm{C}$ \\
\hline $4-1,40-42$ & 12.40 & +3.27 & +0.67 & & & & & & \\
\hline $4-1,124-126$ & 13.24 & +3.38 & +0.88 & & & & & +0.20 & +1.73 \\
\hline $4-2,42-44$ & 13.92 & +3.21 & +0.42 & +3.39 & +0.65 & & & +0.11 & +2.09 \\
\hline $4-2,128-130$ & 14.78 & +3.28 & +0.95 & & & & & +0.13 & +2.14 \\
\hline $4-3,40-42$ & 15.40 & +3.58 & +0.43 & +3.57 & +0.37 & & & +0.22 & +1.88 \\
\hline $4-3,76-78$ & 15.76 & +3.17 & +0.78 & & & & & +0.05 & +1.76 \\
\hline $5-1,100-102$ & 17.50 & & & +2.85 & +0.69 & & & +0.07 & +2.08 \\
\hline $5-2,110-112$ & 19.10 & +2.84 & +0.64 & +3.11 & +0.84 & & & +0.20 & +2.26 \\
\hline $6-2,80-82$ & 23.30 & & & & & & & +0.11 & +2.27 \\
\hline $6-2,130-132$ & 23.80 & +2.94 & +0.72 & +3.27 & +0.54 & & & +0.67 & +2.05 \\
\hline $6-3,80-82$ & 24.80 & & & +2.40 & +0.86 & & & +0.49 & +2.10 \\
\hline $7-2,80-82$ & 27.80 & & & +2.40 & +0.86 & & & +0.51 & +2.05 \\
\hline $8-1,133-135$ & 31.33 & & & +3.55 & -0.46 & +3.07 & +0.73 & & \\
\hline $8-2,34-36$ & 31.84 & +2.46 & +0.89 & +2.70 & +0.80 & & & & \\
\hline $8-2,133-135$ & 32.83 & +2.22 & +0.71 & & & & & & \\
\hline $8-3,34-36$ & 33.34 & +2.45 & +0.65 & +2.41 & +0.30 & & & +0.43 & +1.99 \\
\hline $8-3,100-102$ & 34.00 & & & & & +2.99 & -0.47 & & \\
\hline $9-1,135-137$ & 35.85 & & & +2.72 & +0.80 & & & +0.49 & +1.72 \\
\hline $9-1,140-142$ & 35.90 & +2.38 & +1.07 & & & +2.87 & -0.55 & & \\
\hline $9-2,36-38$ & 36.36 & +2.52 & +1.00 & +2.23 & +0.65 & & & & \\
\hline $9-2,135-137$ & 37.37 & & & +2.41 & +0.57 & & & +0.44 & +2.08 \\
\hline $9-2,140-142$ & 37.40 & +2.26 & +0.96 & +2.06 & +0.47 & +2.33 & -0.86 & & \\
\hline $9-3,36-38$ & 37.86 & +2.48 & +0.94 & +2.46 & +0.61 & & & & \\
\hline $10-1,110-112$ & 40.10 & & & +2.32 & +0.58 & +2.55 & -0.64 & & \\
\hline $10-2,110-112$ & 41.60 & +2.36 & +0.91 & & & +2.00 & -0.83 & & \\
\hline $10-3,76-78$ & 42.76 & & & +2.24 & +0.64 & & & & \\
\hline $11-2,30-32$ & 45.31 & +2.48 & +0.85 & +2.61 & +0.65 & & & & \\
\hline
\end{tabular}

calculated for Oridorsalis umbonatus. Slightly lighter are the averages for Planulina wuellerstorfi $\left(+2.5 \%_{0} \pm\right.$ $0.2 \% 0$ ) and for Nuttalides umbonifera $\left(+2.3 \%_{0} \pm 0.2 \%_{0}\right)$. One excursion to low $\delta^{18} \mathrm{O}$ values interrupts the benthic low-amplitude record at Site 519. The measured values of $+2.1 \%$ fall into the middle of the magnetic $\mathrm{C}-1$ event. We assigned an age of 4.4 m.y. to this excursion by applying the magnetic stratigraphy of LaBrecque et al. (1977) as modified by Mankinen and Dalrymple (1979).

Stable oceanographic conditions are recorded in the early Pliocene planktonic foraminifers as well. An average $\delta^{18} \mathrm{O}$ composition of $+0.5 \% \pm 0.1 \%$ was measured for Globigerinoides sacculifer (Figs. 2 and 3). The oxygen-isotope excursion in the $\mathrm{C}-1$ event is not limited to the benthic record; it is accompanied by a $0.5 \%$ depletion of the heavy ${ }^{18} \mathrm{O}$ isotope in the planktonic samples. The constant ${ }^{13} \mathrm{C}$ curve of the benthic species is only interrupted at $4.4 \mathrm{~m} . y_{\text {., }}$ the time of the negative ${ }^{18} \mathrm{O}$ excur- sion. During this isotopic event the $\delta^{13} \mathrm{C}$ values of $P$. wuellerstorfi are $0.5 \%$ lighter than they are near the Miocene/Pliocene boundary.

During the latest Miocene, the carbonate compensation depth lay between the depth occupied by Sites 521 and 522. The effect of paleodepth on dissolution is shown clearly in Figure 7. In the early Pliocene, the intensity of dissolution decreased at all the sites, and by 3.4 Ma it had reached low degrees at the shallower sites (519 and 521) and moderate degrees at the deeper ones (522 and 523).

\section{Middle Pliocene (3.3-2.5 Ma)}

Near the base of the Gauss magnetic epoch, the benthic ${ }^{18} \mathrm{O}$ data at Sites 519,521 , and 522 shift by $0.5 \%$ to more positive $\delta^{18} \mathrm{O}$ values. For Planulina wuellerstorfi we calculated an average for the middle Pliocene of $+2.85 \pm 0.4 \%$. Nuttalides umbonifera fluctuates around 
Table 1C. Oxygen- and carbon-isotope data (\%o) for Hole 522.

\begin{tabular}{|c|c|c|c|c|c|c|c|c|c|}
\hline \multirow{2}{*}{$\begin{array}{l}\text { Core-Section } \\
\text { (interval in cm) }\end{array}$} & \multirow{2}{*}{$\begin{array}{l}\text { Sub-bottom } \\
\text { depth } \\
\text { (m) }\end{array}$} & \multicolumn{2}{|c|}{$\begin{array}{c}\text { Nuttalides } \\
\text { umbonifera }\end{array}$} & \multicolumn{2}{|c|}{$\begin{array}{l}\text { Oridorsalis } \\
\text { umbonatus }\end{array}$} & \multicolumn{2}{|c|}{$\begin{array}{c}\text { Planulina } \\
\text { wuellerstorfi }\end{array}$} & \multicolumn{2}{|c|}{$\begin{array}{c}\text { Globigerinoides } \\
\text { conglobatus }\end{array}$} \\
\hline & & $\delta^{18} \mathrm{O}$ & $\delta^{13} \mathrm{C}$ & $\delta^{18} \mathrm{O}$ & $\delta^{13} \mathrm{C}$ & $\delta^{18} \mathrm{O}$ & $\delta^{13} \mathrm{C}$ & $\delta^{18} \mathrm{O}$ & $\delta^{13} \mathrm{C}$ \\
\hline $4-1,31-33$ & 11.11 & +2.82 & +0.45 & & & & & +0.83 & +1.91 \\
\hline $4-1,52-54$ & 11.32 & +3.78 & +0.27 & & & & & +0.91 & +1.58 \\
\hline $4-1,90-92$ & 11.70 & +2.66 & +0.44 & & & & & +0.63 & +2.31 \\
\hline $4-1,118-120$ & 11.98 & +3.18 & +0.42 & & & & & +0.71 & +2.07 \\
\hline $4-1,132-134$ & 12.12 & +2.34 & +0.24 & & & & & +0.45 & +2.15 \\
\hline $4-2,54-56$ & 12.84 & +3.28 & +0.60 & & & & & +0.73 & +2.22 \\
\hline $4-2,76-78$ & 13.06 & +3.34 & +0.89 & & & & & +0.75 & +2.04 \\
\hline $4-2,82-84$ & 13.12 & +2.87 & +0.75 & & & & & +0.45 & +2.14 \\
\hline $4-2,104-106$ & 13.34 & +3.84 & +0.33 & & & & & +0.37 & +1.76 \\
\hline $4-2,131-133$ & 13.61 & +3.49 & +0.45 & & & & & +0.62 & +1.77 \\
\hline $4-2,146-148$ & 13.76 & +3.71 & +0.29 & & & & & +0.76 & +1.70 \\
\hline $4-3,14-16$ & 13.94 & +3.56 & +0.45 & & & & & +0.61 & +1.79 \\
\hline $4-3,37-39$ & 14.17 & +3.47 & -0.03 & & & & & +0.89 & +1.68 \\
\hline $4-3,56-58$ & 14.36 & +2.57 & +0.48 & & & & & +0.18 & +1.95 \\
\hline $5-1,83-85$ & 16.03 & +2.48 & +0.63 & & & & & +0.22 & +2.16 \\
\hline $5-1,138-140$ & 16.58 & +3.45 & +0.14 & +3.37 & -0.44 & +3.65 & +0.48 & & \\
\hline $5-3,20-22$ & 18.40 & +2.74 & +0.69 & +2.06 & -1.29 & & & & \\
\hline $6-1,78-80$ & 20.38 & +3.21 & +0.69 & +3.77 & -0.55 & +3.17 & +0.73 & & \\
\hline $6-2,50-52$ & 21.60 & +1.72 & +0.05 & & & +2.61 & +0.66 & & \\
\hline $7-1,32-34$ & 24.32 & +2.39 & +0.46 & & & +2.75 & +0.85 & & \\
\hline $7-2,39-41$ & 25.89 & +1.87 & +0.35 & +2.80 & -0.44 & +2.50 & +0.63 & & \\
\hline $7-3,40-42$ & 27.40 & +2.56 & +0.64 & & & +2.50 & +0.89 & & \\
\hline $8-2,25-27$ & 30.15 & +2.16 & +0.47 & +2.85 & -0.36 & +2.40 & +0.94 & & \\
\hline
\end{tabular}

Table 1D. Oxygen- and carbon-isotope data (\%) for Hole 523.

\begin{tabular}{|c|c|c|c|c|c|c|c|c|c|}
\hline \multirow{2}{*}{$\begin{array}{l}\text { Core-Section } \\
\text { (interval in cm) }\end{array}$} & \multirow{2}{*}{$\begin{array}{l}\text { Sub-bottom } \\
\text { depth } \\
\text { (m) }\end{array}$} & \multicolumn{2}{|c|}{$\begin{array}{c}\text { Planulina } \\
\text { wuellerstorfi }\end{array}$} & \multicolumn{2}{|c|}{$\begin{array}{l}\text { Oridorsalis } \\
\text { umbonatus }\end{array}$} & \multicolumn{2}{|c|}{$\begin{array}{c}\text { Nuttalides } \\
\text { umbonifera }\end{array}$} & \multicolumn{2}{|c|}{$\begin{array}{c}\text { Globigerinoides } \\
\text { ruber }\end{array}$} \\
\hline & & $\delta^{18} \mathrm{O}$ & $\overline{\delta^{13} \mathrm{C}}$ & $\delta^{18} \mathrm{O}$ & $\delta^{13} \mathrm{C}$ & $\delta^{18} \mathrm{O}$ & $\delta^{13} \mathrm{C}$ & $\delta^{18} \mathrm{O}$ & $\delta^{13} \mathrm{C}$ \\
\hline $2-2,23-25$ & 5.75 & +2.93 & +0.49 & & & & & +0.52 & +1.06 \\
\hline $2-2,41-43$ & 5.93 & & & & & & & +0.44 & +0.52 \\
\hline $2-2,63-65$ & 6.13 & & & & & & & +0.71 & +1.04 \\
\hline $3-1,98-100$ & 9.38 & +3.06 & +0.61 & & & & & & \\
\hline $3-1,112-114$ & 9.52 & +3.35 & +0.11 & & & & & +0.93 & +0.98 \\
\hline $3-1,123-125$ & 9.63 & +3.13 & +0.42 & +3.33 & -1.12 & +3.60 & +0.46 & & \\
\hline $3-1,126-128$ & 9.66 & +3.02 & +0.45 & & & & & +0.76 & +1.31 \\
\hline $3-2,20-22$ & 10.10 & +3.02 & +0.73 & & & & & +1.31 & +1.37 \\
\hline $3-2,45-47$ & 10.35 & +3.69 & -0.56 & & & & & +1.33 & +0.86 \\
\hline $3-2,65-67$ & 1 & +2.56 & -0.17 & & & & & +0.85 & +1.05 \\
\hline $3-2,80-82$ & 10.70 & +3.75 & -0.10 & & & & & +1.41 & +0.95 \\
\hline $3-2,110-112$ & 11.00 & +2.67 & +0.29 & & & & & +0.96 & +0.74 \\
\hline $3-2,131-133$ & 11.21 & +2.58 & -0.17 & & & & & +0.95 & +0.96 \\
\hline $3-3,3-5$ & 11.43 & +2.99 & +0.18 & +3.33 & -1.11 & +3.19 & +0.31 & & \\
\hline $4-1,119-121$ & 1 & +2.73 & +0.17 & & & & & & \\
\hline $4-2,97-99$ & 15.17 & +2.78 & +0.84 & & & & & +0.99 & +0.93 \\
\hline $4-2,132-134$ & 15.52 & +2.99 & +0.70 & & & & & +1.08 & +1.04 \\
\hline $4-3,23-25$ & 15.93 & +2.62 & +0.73 & +3.16 & -0.67 & +3.41 & +0.50 & & \\
\hline $4-3,80-82$ & 16.50 & +2.83 & +0.93 & +2.75 & -0.74 & +2.30 & +0.40 & & \\
\hline $5-3,150-152$ & 17.60 & +2.98 & +0.38 & & & & & & \\
\hline $6-2,40-42$ & 23.50 & +2.67 & +0.74 & & & +3.87 & -0.13 & +0.98 & +0.95 \\
\hline $6-2,76-78$ & 23.85 & & & +2.38 & -0.68 & +2.64 & +0 & & \\
\hline $6-2,105-107$ & 24.15 & +2.74 & +0.38 & & & & & & \\
\hline $6-3,10-12$ & 24.70 & +2.60 & +0.91 & +2.82 & -0.68 & +2.64 & +0.61 & & \\
\hline $6-3,71-73$ & 25.30 & +2.32 & +0.76 & & & & & +0.80 & +0.93 \\
\hline $6-3,85-87$ & 25.45 & +2.42 & +0.67 & & & & & +1.15 & +0.90 \\
\hline
\end{tabular}

an average mean of $+2.88 \pm 0.4 \%$, and Oridorsalis umbonatus fluctuates around $3.06 \pm 0.7 \%$. The large standard deviation reflects the high-amplitude fluctuations in the middle Pliocene record, with low ${ }^{18} \mathrm{O}$ values of +2.0 to $+2.5 \%$ on the negative side and of up to $+3.7 \%$ on the positive side of the curve.

The planktonic oxygen-isotope values contrast with the benthic sequence. Globigerinoides sacculifer at Sites 519 and 521 does not change its isotopic composition throughout the early and middle Pliocene. The average is $+0.5 \%$, with a small standard deviation of $\pm 0.1 \%$.

The benthic carbon-isotope signature in the middle Pliocene differs slightly from that in the early Pliocene. Values of $+0.7 \%$ measured on $P$. wuellerstorfi at the 3.2-m.y. level are more negative by $0.3 \%$ than the values at $3.4 \mathrm{Ma}$. The carbon-isotope signal for $O$. umbonatus throughout the early and middle Pliocene is extremely unstable, while the shape of the ${ }^{13} \mathrm{C}$ curve of $G$. sacculifer remains uniform, with values of $+2.0 \% \pm$ $0.1 \%$.

The degree of dissolution remained constant in the middle Pliocene (Fig. 7). Only near the end of the period was there an increase in dissolution, heralding the onset of fluctuating conditions in the late Pliocene.

\section{Late Pliocene and Early Pleistocene (2.5-1.1 Ma)}

We established a detailed isotope record in the alternating dark and light nannofossil ooze in the late Pliocene-early Pleistocene sediments of Sites 522 and 523 (Fig. 8). Additional data from Site 521 (not shown) document a second, minor shift in the benthic oxygenisotope curve of the Pliocene. An average value of $+3.21 \pm 0.4 \%$ for Planulina wuellerstorfi was calculated for this time interval.

The degree to which the alternating light and dark sediment layers can be recognized is a function of paleo- 


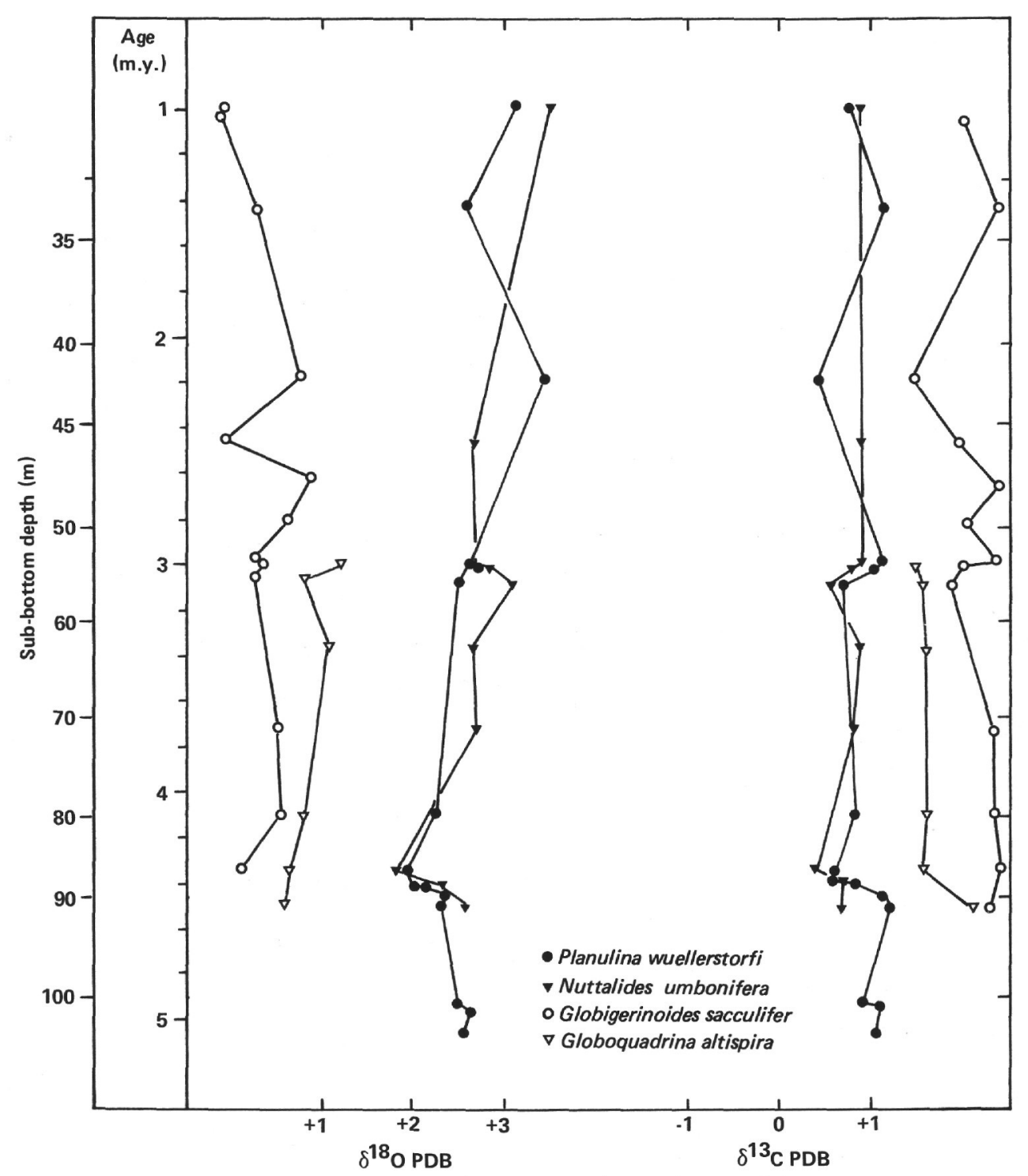

Figure 2. Pliocene oxygen- and carbon-isotope stratigraphy of Site 519. Absolute age determinations are based on direct interpolation between magnetic polarity reversals.

depth. Sites $519,521,522$, and 523 lie at progressively deeper positions today. During the late Pliocene, when these layers were deposited, the water depth was approximately $3650,4025,4400$, and $4525 \mathrm{~m}$, respectively. The layers at Site 522 are the best preserved. At Site 523, which lay a bit more than $100 \mathrm{~m}$ deeper, the contrast between the layers is strong, but the boundaries between them are less sharply defined. At Site 521 (approximately $400 \mathrm{~m}$ higher than Site 522), the layering is evident but more obscure. At Site 519, which lay more than $700 \mathrm{~m}$ above Site 522, there are color changes in the sediment column, but it is not possible to easily correlate them with the sharply defined layers of Site 522.

Two major observations relative to the light and dark layers can be made. One is that a number of isotopic and micropaleontological parameters correlate strongly with the layers (Fig. 9). The second is that there is a temporal correlation between the isotopic record of different sites.
Two types of statistical tests were performed on the data of Figure 9 to test the visual correlations. A runs test (Table 2) was conducted to determine whether the number of reversals in values across light/dark boundaries could be attributed to chance. In every case except the percentage. of Nuttalides umbonifera, the data are judged to be significantly nonrandom in their distribution; that is, there is a reversal in trend when one crosses a color boundary. In addition to testing the sequence of reversals in the data, the magnitude of the change across light/dark boundaries was examined at both Site $\mathbf{5 2 2}$ and Site 523. Table 3 exhibits the results of this examination. At both sites the differences between the isotopic means are judged to be significant, although at Site $\mathbf{5 2 3}$ the probability of being wrong is somewhat greater as a result of the greater difficulty in defining light and dark layers.

The maximum isotopic excursions across a light/dark boundary are $0.8 \%$ for planktonic $\delta^{18} \mathrm{O}$ values, $0.7 \%$ 


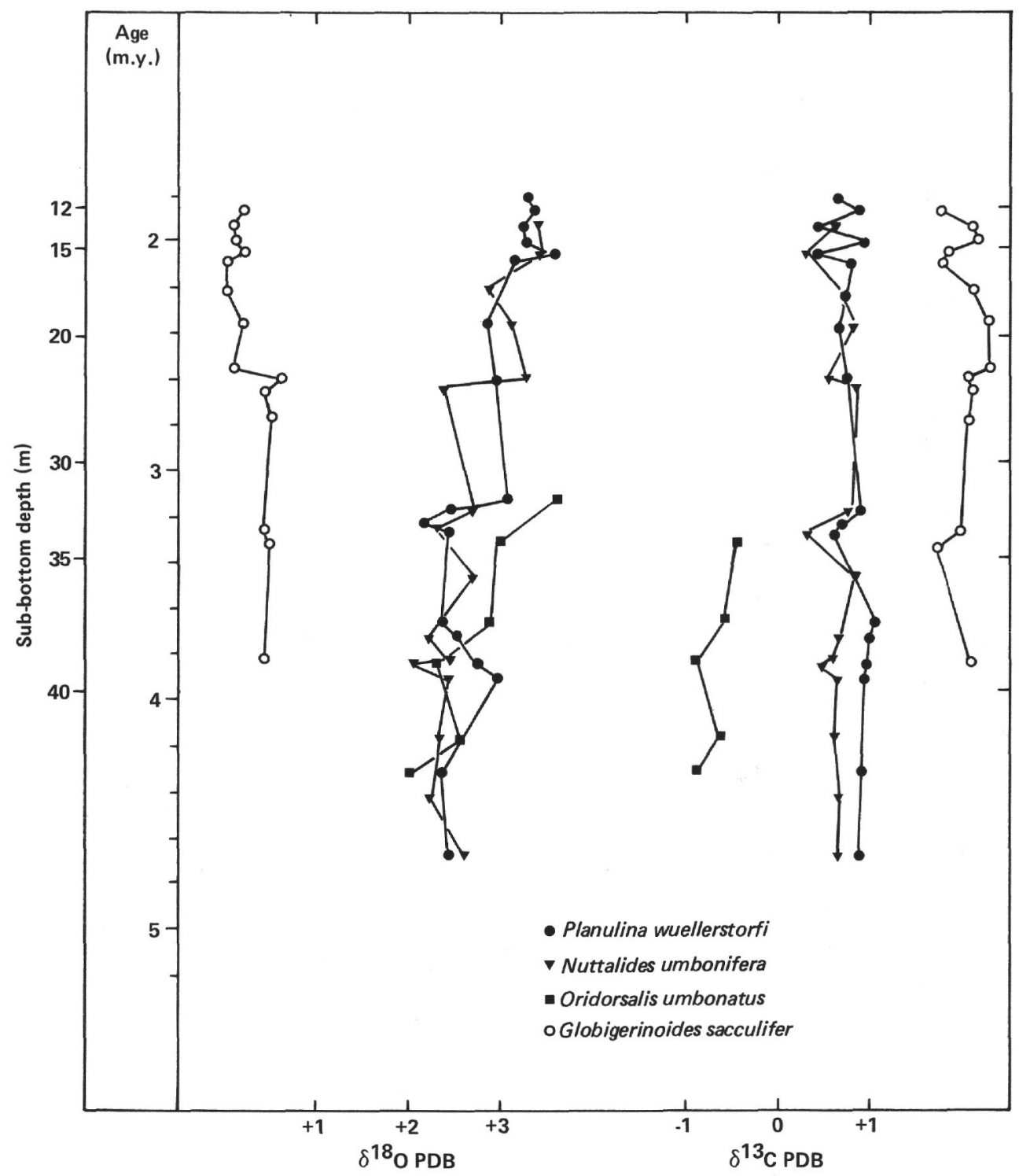

Figure 3. Pliocene oxygen- and carbon-isotope stratigraphy of Site 521. Absolute age determinations are based on direct interpolation between magnetic polarity reversals.

Table 2. Statistical significance of the number of runs (reversals in value) for isotopic and micropaleontological parameters, light and dark sediment layers, late Pliocene, Hole 522.

\begin{tabular}{lccc}
\hline \multicolumn{1}{c}{ Parameter } & $\begin{array}{c}\text { Number } \\
\text { of } \\
\text { layers }\end{array}$ & $\begin{array}{c}\text { Number } \\
\text { of } \\
\text { runs }\end{array}$ & $\begin{array}{c}\text { Probability of } \\
\text { Type I error } \\
\text { if Ho rejected }\end{array}$ \\
\hline Planktonic $\delta^{18} \mathrm{O}$ & 14 & 13 & 0.001 \\
Planktonic $\delta^{13} \mathrm{C}$ & 14 & 12 & 0.004 \\
Benthic $\delta^{18} \mathrm{O}$ & 14 & 11 & 0.025 \\
Benthic $\delta^{13} \mathrm{C}$ & 14 & 12 & 0.004 \\
Benthic foraminifers $(\%)^{\mathrm{a}}$ & 16 & 14 & 0.001 \\
Foraminifer fragments (\%) & 16 & 12 & 0.025 \\
Nuttalides umbonifera $(\%)^{\mathrm{c}}$ & 16 & 9 & 0.378 \\
\hline
\end{tabular}

Note: Ho is the hypothesis that the values of parameters are randomly distributed.

a Relative to entire foraminifer population.

$\mathrm{b}$ Relative to fragments and whole tests.

c Relative to the benthic assemblage. for planktonic $\delta^{13} \mathrm{C}$ values, $1.2 \%$ for benthic $\delta^{18} \mathrm{O}$ values, and $1.3 \%$ for benthic $\delta^{13} \mathrm{C}$ values.

The differences between means of the micropaleontological parameters are generally significant, with two exceptions. At Site 522 the proportion of $N$. umbonifera shows no significant difference, and at Site 523 the difference between the degree of fragmentation in light and dark layers is not significant. In the case of Site $\mathbf{5 2 2}$ the reason that the percentage of $N$. umbonifera fails to show either a nonrandom pattern of reversals from light to dark layers (Table 2) or a significant difference in mean value between layers (Table 3) can be seen in the behavior of this species relative to carbonate undersaturation (Fig. 10). The least scatter (best correlation) in the data in deep water occurs in the region where carbonate undersaturation is greatest. These are generally the deeper areas. At the deeper Site 523 the dark layers are significantly enriched in $N$. umbonifera as a func- 


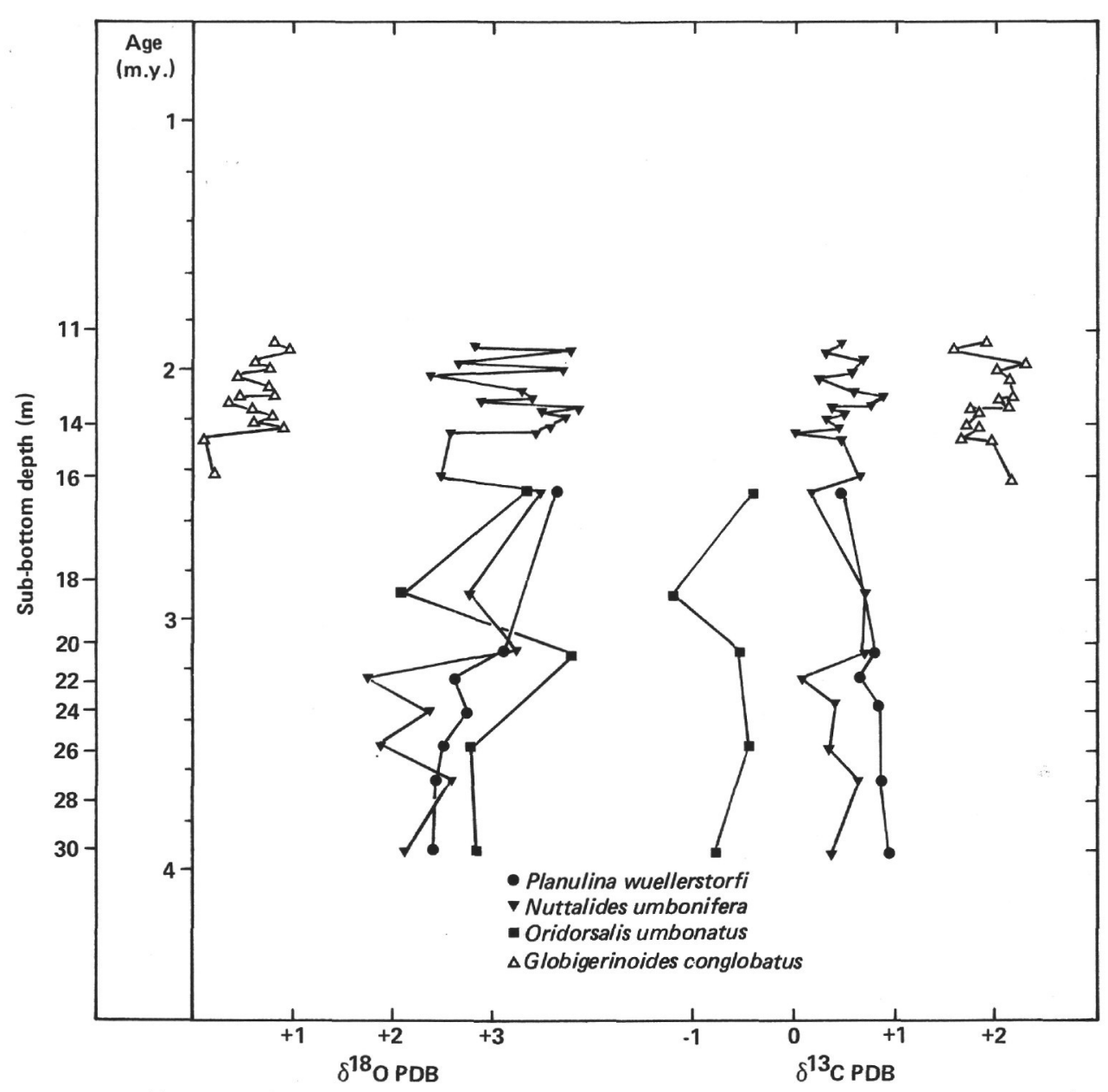

Figure 4. Pliocene oxygen- and carbon-isotope stratigraphy of DSDP Site 522. Absolute age determinations are based on direct interpolation between magnetic polarity reversals.

Table 3. Statistical significance of differences between means of light and dark sediment layers for several parameters, late Pliocene, Holes 522 and 523.

\begin{tabular}{|c|c|c|c|c|c|c|c|}
\hline \multirow[b]{2}{*}{ Parameter } & \multicolumn{2}{|c|}{ Light layer } & \multicolumn{2}{|c|}{ Dark layer } & \multirow[b]{2}{*}{$\mathrm{df}$} & \multirow[b]{2}{*}{${ }^{t} d f$} & \multirow{2}{*}{$\begin{array}{l}\text { Probability of } \\
\text { Type I error } \\
\text { if Ho rejected }\end{array}$} \\
\hline & Mean & $\begin{array}{l}\text { Number of } \\
\text { layers }\end{array}$ & Mean & $\begin{array}{c}\text { Number of } \\
\text { layers }\end{array}$ & & & \\
\hline \multicolumn{8}{|l|}{ Hole 522} \\
\hline $\begin{array}{l}\text { Planktonic } \delta^{18} \mathrm{O}(\%) \\
\text { Planktonic } \delta^{13} \mathrm{C}(\%) \\
\text { Benthic } \delta^{18} \mathrm{O}(\%) \\
\text { Benthic } \delta^{13} \mathrm{C}(\%) \\
\text { Benthic foraminifers }(\%)^{\mathrm{a}} \\
\text { Foraminifer fragments (\%) } \\
\text { Nuttalides umbonifera }(\%)^{\mathrm{a}}\end{array}$ & $\begin{array}{r}0.53 \\
2.02 \\
2.90 \\
0.53 \\
5.31 \\
48.88 \\
50.51\end{array}$ & $\begin{array}{r}9 \\
9 \\
9 \\
9 \\
9 \\
15 \\
15 \\
12\end{array}$ & $\begin{array}{r}0.73 \\
1.84 \\
3.53 \\
0.29 \\
32.62 \\
72.72 \\
59.39\end{array}$ & $\begin{array}{l}6 \\
6 \\
7 \\
7 \\
7 \\
7 \\
7 \\
7\end{array}$ & $\begin{array}{l}13 \\
13 \\
14 \\
14 \\
20 \\
20 \\
17\end{array}$ & $\begin{array}{r}-1.812 \\
1.701 \\
-3.279 \\
2.453 \\
-3.720 \\
-2.668 \\
-1.242\end{array}$ & $\begin{array}{l}0.047 \\
0.056 \\
0.003 \\
0.014 \\
0.001 \\
0.008 \\
0.232\end{array}$ \\
\hline \multicolumn{8}{|l|}{ Hole 523} \\
\hline $\begin{array}{l}\text { Planktonic } \delta^{18} \mathrm{O}(\%) \\
\text { Planktonic } \delta^{13} \mathrm{C}(\%) \\
\text { Benthic } \delta^{18} \mathrm{O}(\%) \\
\text { Benthic } \delta^{13} \mathrm{C}(\%) \\
\text { Benthic foraminifers }(\%)^{\mathrm{a}} \\
\text { Foraminifer fragments }(\%)^{\mathrm{a}} \\
\text { Nuttalides umbonifera }(\%)^{\mathrm{a}}\end{array}$ & $\begin{array}{r}0.96 \\
1.12 \\
2.80 \\
0.56 \\
11.70 \\
74.70 \\
33.50\end{array}$ & $\begin{array}{r}6 \\
6 \\
12 \\
12 \\
6 \\
6 \\
6 \\
6\end{array}$ & $\begin{array}{r}1.14 \\
0.96 \\
3.25 \\
0.07 \\
24.70 \\
85.30 \\
57.00\end{array}$ & $\begin{array}{l}5 \\
5 \\
6 \\
6 \\
3 \\
3 \\
3\end{array}$ & $\begin{array}{r}9 \\
9 \\
16 \\
16 \\
7 \\
7 \\
7\end{array}$ & $\begin{array}{r}-1.481 \\
1.870 \\
-3.085 \\
2.528 \\
-3.775 \\
-1.079 \\
-2.952\end{array}$ & $\begin{array}{l}0.173 \\
0.094 \\
0.007 \\
0.022 \\
0.012 \\
0.316 \\
0.021\end{array}$ \\
\hline
\end{tabular}

Note: $\mathrm{df}=$ degrees of freedom, $\mathrm{t}_{\mathrm{df}}=$ Student's $\mathrm{t}, \mathrm{Ho}$ is the hypothesis that $\mu_{1}=\mu_{2}$ where $\mu=$ mean

a Percentages are as defined in Table 2.

tion of greater carbonate undersaturation. At the shallower Site 522 the correlation of undersaturation with $N$. umbonifera is insufficiently strong to generate a significant difference between light and dark layers, although there is only a $23 \%$ probability of being wrong if one rejects the null hypothesis of equal proportions of $N$. umbonifera. In addition, the behavior of the other micropaleontological parameters (percentage of benthic tests and fragments) indicates that a correlation with carbonate dissolution does exist between the light and dark layers.

That the degree of fragmentation is insignificantly different between the light and dark layers at the deepest site (Table 3) is also related to depth control, at least in- 


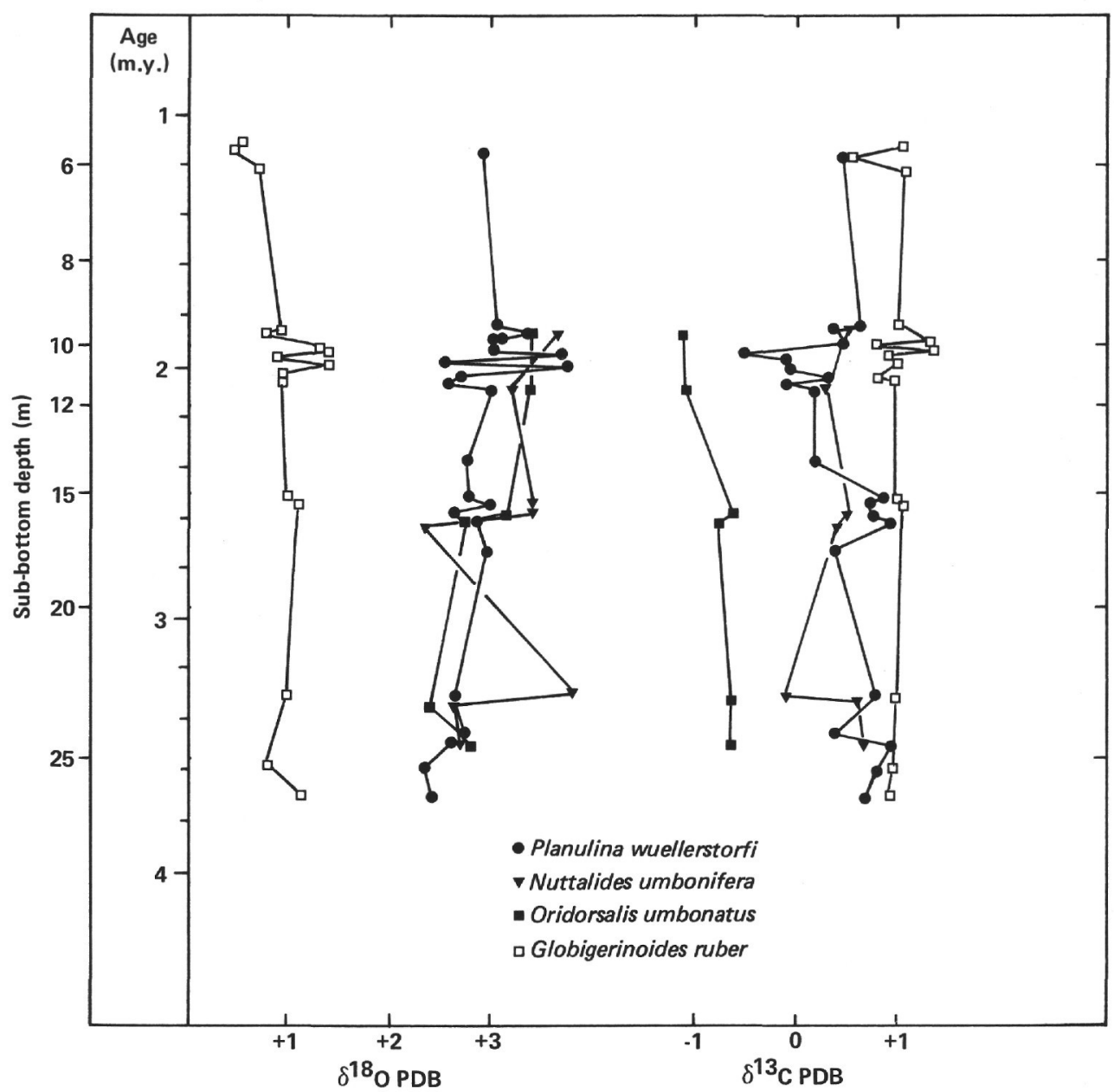

Figure 5. Pliocene oxygen- and carbon-isotope stratigraphy of Site 523. Absolute age determinations are based on direct interpolation between magnetic polarity reversals.

directly. To understand this relation it is necessary to view the connection between dissolution and the behavior of foraminiferal tests. As carbonate dissolution acts on tests, planktonic tests are first affected by removal of the outer lamellae of calcite; the test is weakened and test fragments are generated. Eventually, entire tests are fragmented and the proportion of benthic to whole planktonic tests increases. As dissolution continues to intensify, the fragments become smaller and more difficult to recognize, and they begin to pass through the sieves used in sample preparation. Consequently, the degree of fragmentation is a sensitive measure of low to moderate amounts of carbonate removal, whereas the proportion of benthic tests is a sensitive measure of moderate to high dissolution. This relationship is shown graphically in Figure 11.

The lack of significant difference between the degree of fragmentation between light and dark layers at Site 523 (Table 3) occurs because dissolution was intense enough at this paleodepth so that the increased dissolution in the dark layers made little difference in the degree of fragmentation. However, the proportion of benthic tests still provides a good indicator of the extent of carbonate removal at this depth.

An examination of isotopic behavior of all the late Pliocene sediments at Sites 519 and 521 (both the light and dark layers) reveals a negative oxygen-isotope shift of $0.4 \%$ at $2.4 \mathrm{~m} . \mathrm{y}$. to values of $0.1 \pm 0.1 \%$ in the planktonic record.

\section{DISCUSSION}

Under equilibrium conditions, the oxygen-isotope composition in calcite is controlled by two factors, the oxygen-isotope signature $\left(\delta_{\mathrm{w}}\right)$ and the temperature $(\mathrm{T})$ of the ambient water mass (Epstein et al., 1953). The value of $\delta_{\mathrm{w}}$ is strongly affected by relative changes in the global continental ice volume. During ice ages, ${ }^{16} \mathrm{O}$ is preferentially stored in continental ice. Consequently, the average composition of seawater shifts $\delta_{w}$ to more positive values. A record of changing ice volume is provided by benthic oxygen-isotope stratigraphy, if we assume that the Pliocene bottom-water temperature in the deep South Atlantic was not significantly different from that of the present day. The planktonic record is affected by changes in $\delta_{w}$ and in the temperature of the surface water. The benthic record helps to evaluate the size of the glacial effect, and the residual planktonic curve represents the temperature history of the upper water masses. A detailed knowledge of the oceanic surface-water temperatures is of importance for any heat budget reconstructions during glacial and interglacial cycles. 


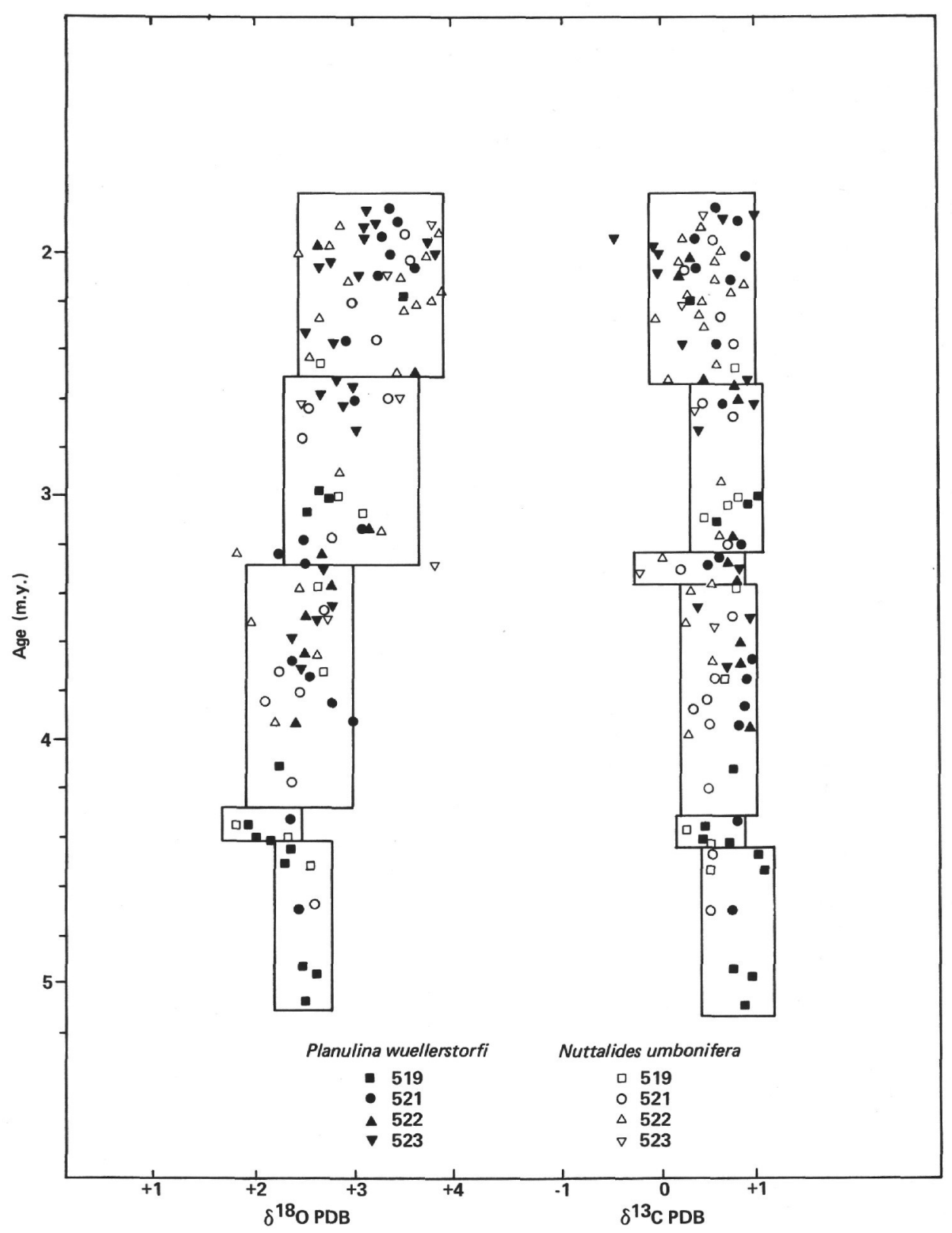

Figure 6. Composite Pliocene benthic isotope record of Sites 519, 521, 522, and 523. The Pliocene is informally subdivided into three paleoclimatic episodes: early Pliocene (5.2-3.3 m.y.), middle Pliocene (3.3-2.5 m.y.), and late Pliocene (2.5-1.9 m.y.).

The carbon-isotope composition reflects the isotopic composition of the dissolved $\mathrm{CO}_{2}$ in seawater. Fluctuations in the benthic ${ }^{13} \mathrm{C}$ record may therefore reflect changes in the chemistry of the bottom water due to changes in abyssal circulation. The ${ }^{13} \mathrm{C}$ composition of the planktonic foraminifers is strongly controlled by productivity in surface water.

\section{Early Pliocene}

The low-amplitude benthic oxygen curve mirrors stable oceanographic conditions during the early Pliocene. The small variability observed in benthic ${ }^{18} \mathrm{O}$ suggests that between 5.0 and $3.3 \mathrm{Ma}$, climatic differences and fluctuations in Antarctic ice volume between colder and warmer periods were less pronounced than in the late Pliocene and Pleistocene. Exceptionally low values measured in the middle of the C-1 event represent a period of diminished Southern Hemisphere glaciation. This climatic event may be correlated with an early Pliocene marine invasion of Pecten into the Wright Valley in Antarctica. This marine invasion further documents the period of shrunken glaciers described by Webb (1972) and Ciesielski and Weaver (1974). Warmer temperatures in the early Pliocene of the Southern Ocean were coupled with this episode of diminished glaciation, as documented in the silicoflagellate paleotemperature study by Ciesielski and Weaver (1974). No temperature change in the South Atlantic surface water can be observed for the early Pliocene.

If we accept the assumption that the bottom-water temperature of the early Pliocene South Atlantic Ocean was comparable to that of today we can conclude that 


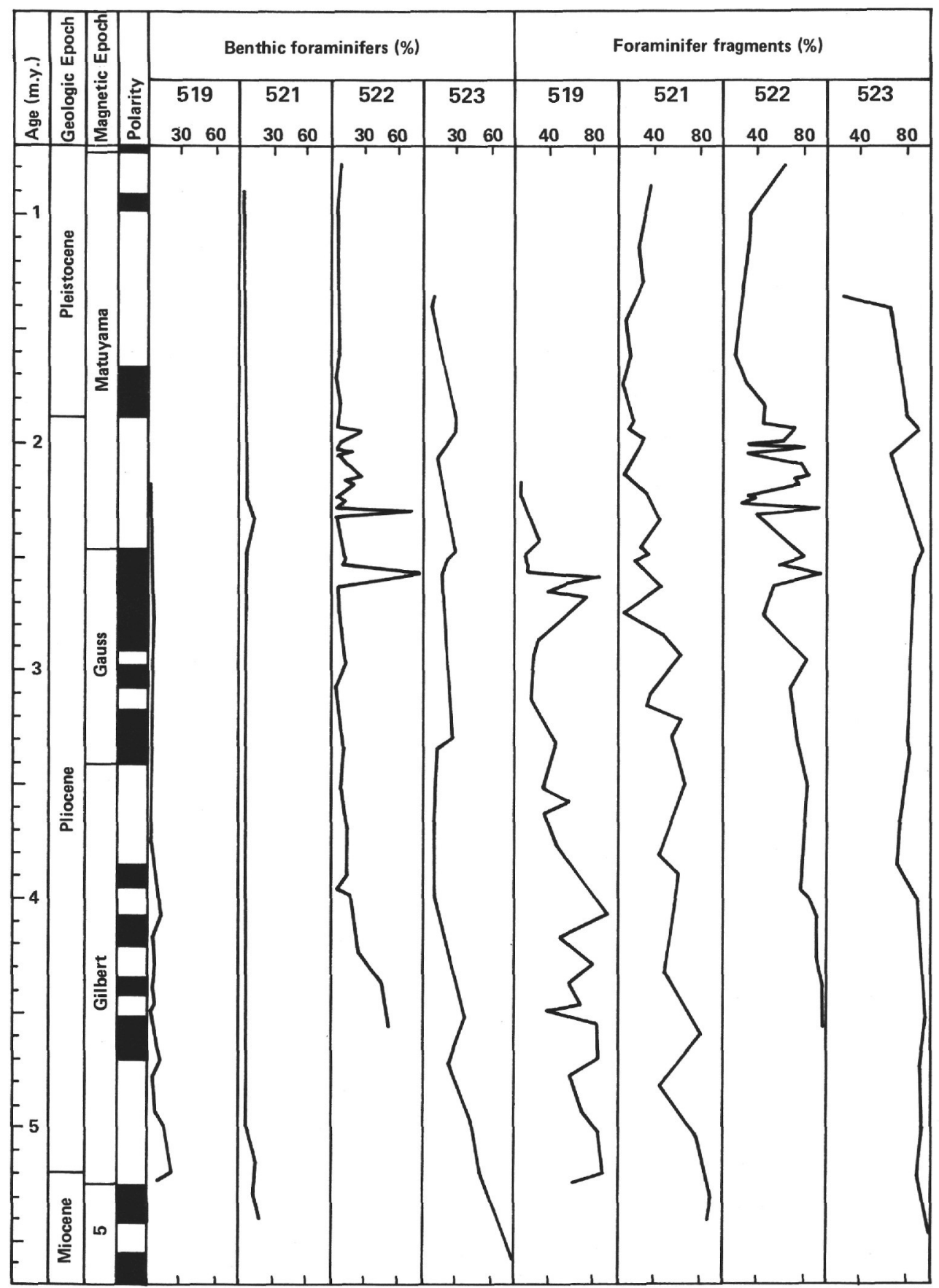

Figure 7. Pliocene dissolution patterns, eastern South Atlantic. Absolute age determinations for Sites 519,521 , and 522 are based on direct interpolation between magnetic polarity reversals. For Site 523 they are tied to magnetic reversals indirectly, via calcareous nannoplankton datums.

the oxygen-isotope composition, $\delta_{\mathrm{w}}$, of early Pliocene seawater was around $0.5 \%$ more negative than presentday ocean water. Woodruff et al. (1980) measured average $\delta^{18} \mathrm{O}$ values of $+2.75 \%$ for Recent Planulina wuellerstorfi from the equatorial Pacific. These values are about $0.5 \%$ more positive than the numbers for early Pliocene interglacial $P$. wuellerstorfi.

\section{Middle Pliocene}

Near the base of the Gauss the low-amplitude changes in the benthic oxygen-isotope curve are succeeded by high-amplitude fluctuations and by a positive shift in the average $\delta^{18} \mathrm{O}$ composition. This marked change mirrors fundamental changes in Pliocene glacial history. A $0.4 \%$ positive shift in the average mean of the benthic values, coupled with a large standard deviation, reflects not only an increase in the difference, $\delta_{\mathrm{f}}$, between positive glacial and negative interglacial times but also a net change in the average global ice volume. The observed shift, which is given a date of $3.3 \mathrm{~m} . y$. , documents the growth of the Southern Hemisphere ice volume. About 3.5 Ma the circum-Antarctic glacial marine depositional belt began to shift northward as a result of the growth of glaciers in Antarctica (Ciesielski and 

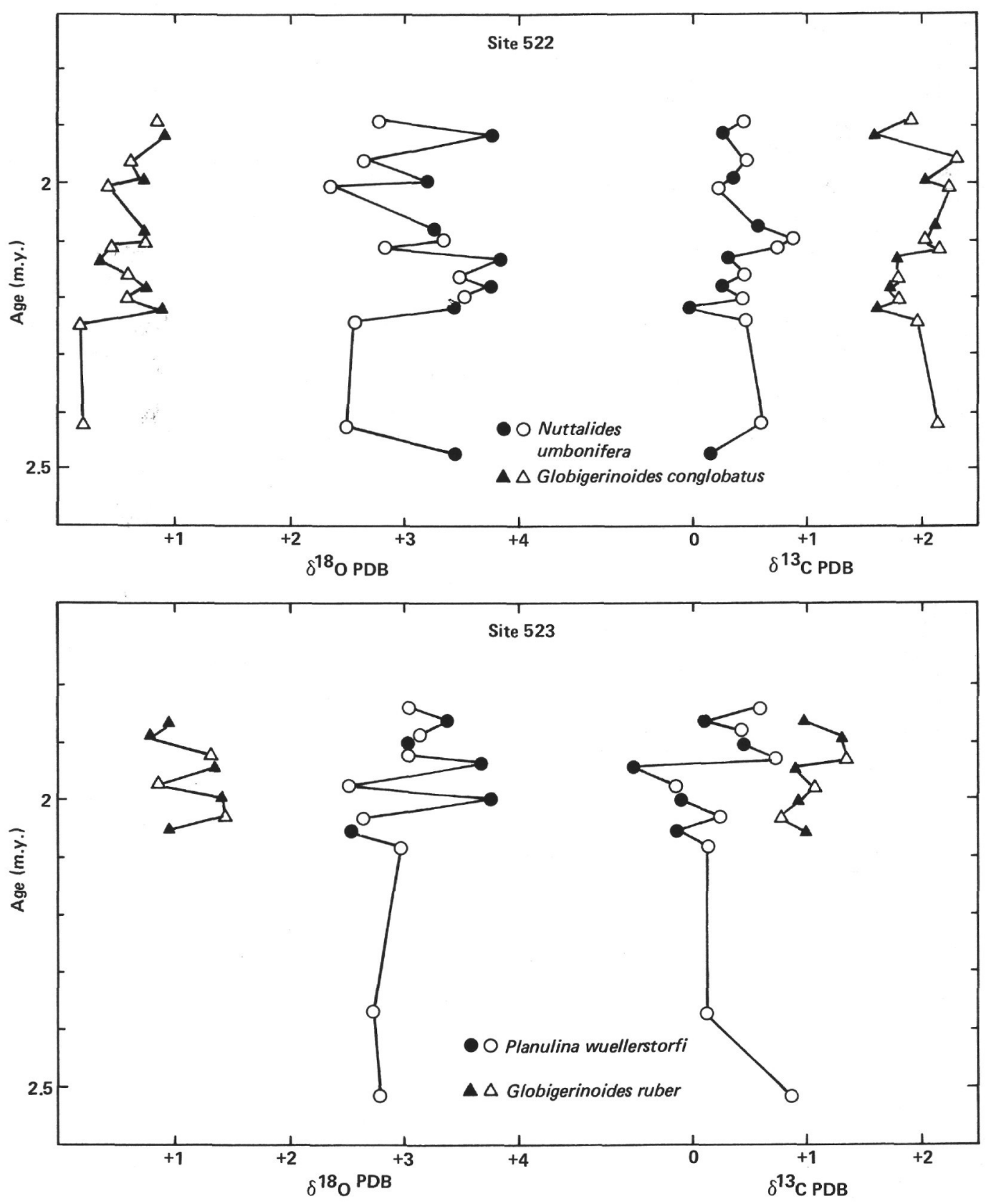

Figure 8. Isotope stratigraphy of late Pliocene, showing alternating dark and light nannofossil ooze sequence at Sites 522 and 523. Filled circles: samples from dark layers. Open circles: samples from light layers.

Weaver, 1974). Indications of the growth of glaciers are also found in Patagonia (Mercer, 1976). The first glacial marine deposits in the Pliocene of the Northern Hemisphere, which are dated as $3.2 \mathrm{~m} . y$. old, are construed as evidence for the widespread glaciation of the Northern Hemisphere (Berggren, 1972). An oxygen-isotope shift like that we observed in the South Atlantic has been reported from the Mediterranean (Keigwin and Thunnell, 1979), from the central North Atlantic (Shackleton and Cita, 1979), and from the Pacific Ocean (Shackleton and Opdyke, 1977; and Keigwin, 1979). Ledbetter et al. (1978) analyzed deep sea sediments from the South Atlantic. They interpreted periods of intense sediment winnowing around $3.2 \mathrm{Ma}$ as indicators of enhanced bottom-current activity due to the growth of glaciers in the Antarctic realm. As the global cooling took place, the differences between glacials and interglacials intensified. More widespread glaciations alternated with periods of reduced glaciers, periods that did not differ markedly from the early Pliocene interglacials. The difference of 1.0 to $1.3 \%$ between cold and warm periods was already within the range of values typical for the Pleistocene (Shackleton and Opdyke, 1976). The middle Pliocene ${ }^{18} \mathrm{O}$ composition of Planulina wuellerstorf $i$ picked from interglacial sediments has an average value of $+2.7 \pm 0.2 \%$, an average that is comparable to $\mathrm{Re}-$ cent values for $\boldsymbol{P}$. wuellerstorfi (Woodruff et al., 1980).

The transition from a warm early Pliocene to a cooler middle Pliocene is not reflected in the planktonic oxygenisotope record. Constant values are recorded through- 


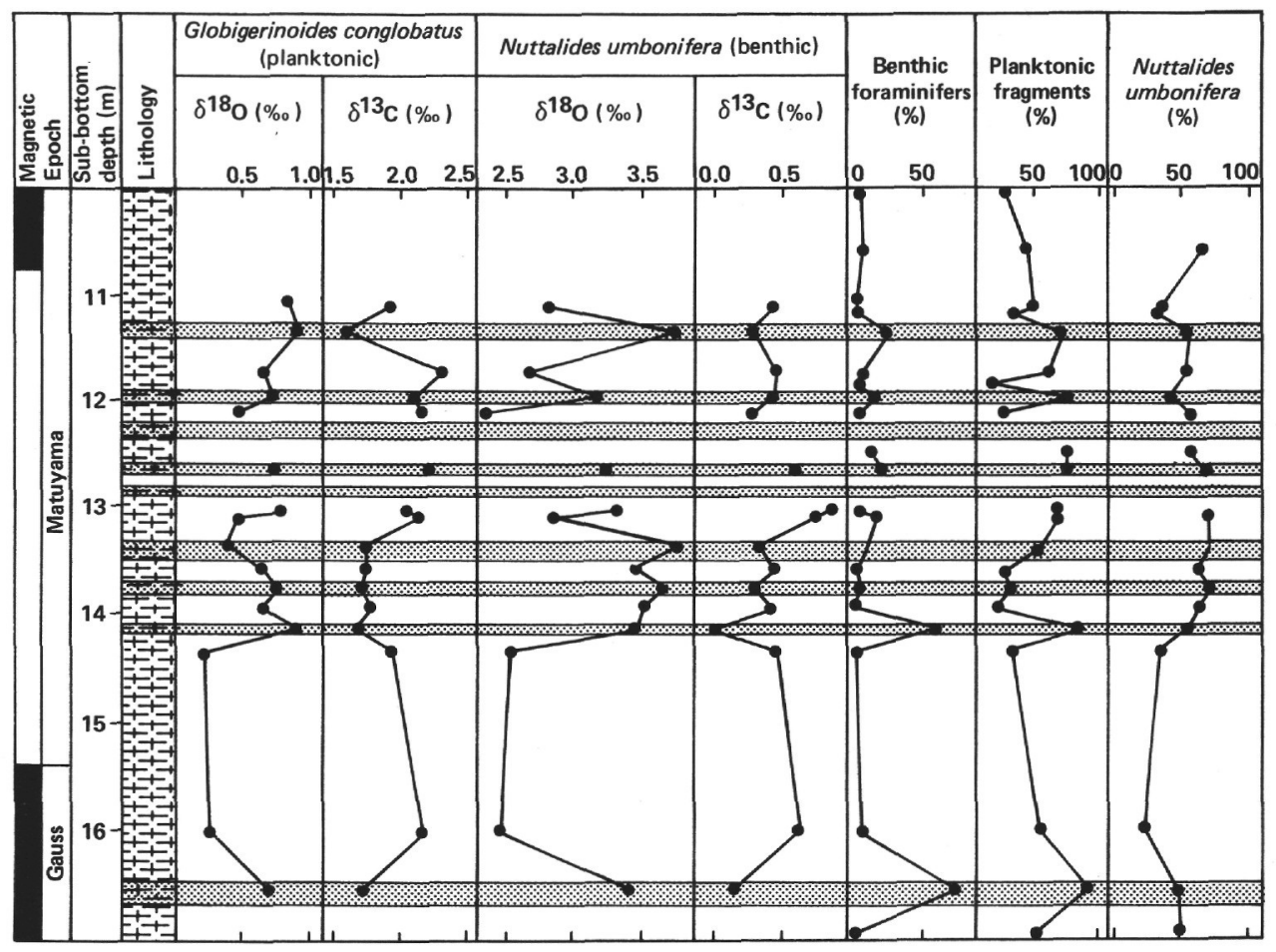

Figure 9. Relationship between sediment type and several isotopic and micropaleontological parameters for the late Pliocene. Data are for Hole 522.

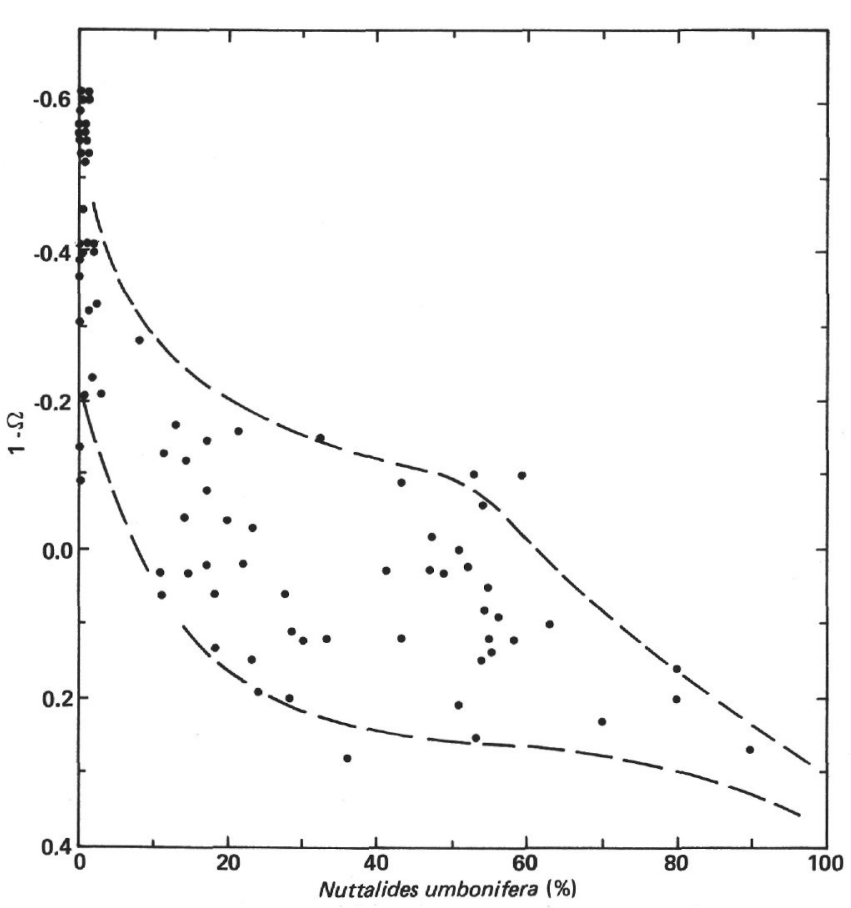

Figure 10. Proportion of Nuttalides umbonifera in Atlantic core top samples as a function of carbonate undersaturation $(1-\Omega)$. The zero value of $1-\Omega$ represents the chemical lysocline. Figure is based on GEOSECS (Geochemical Ocean Sections Study) data for the Atlantic Ocean and unpublished data from Mary Bremer (1982).

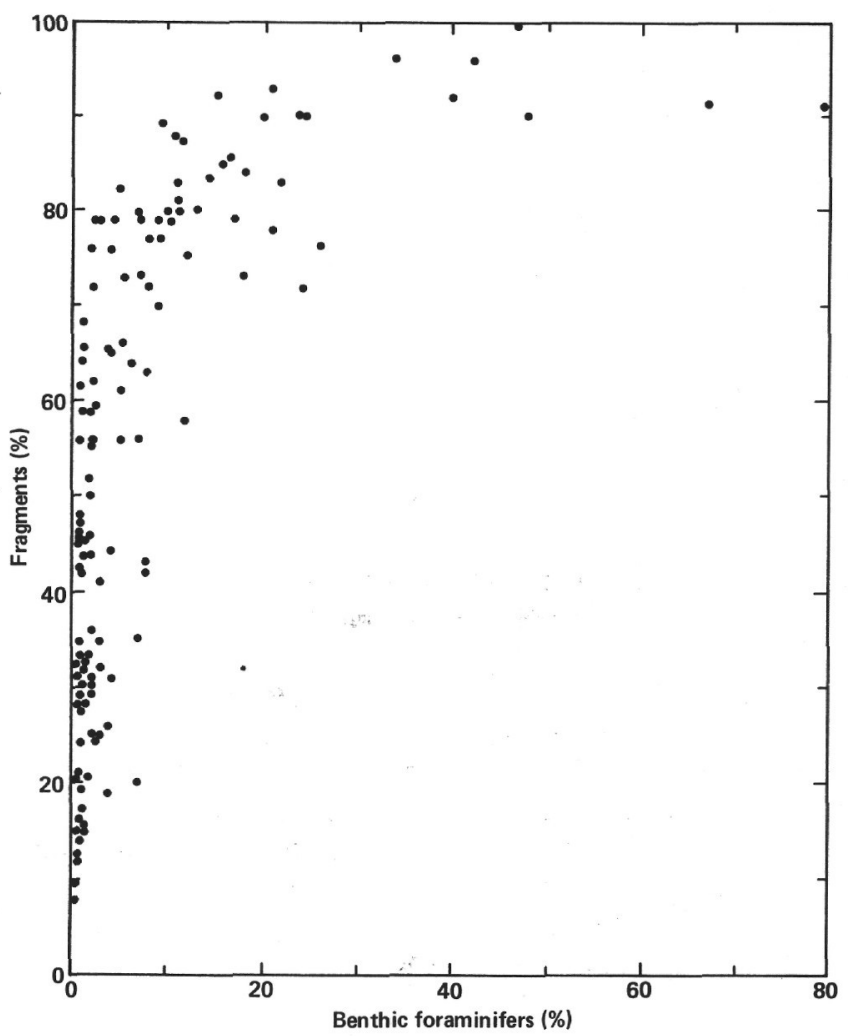

Figure 11. Relationship between the degree of planktonic foraminiferal fragmentation and proportion of benthic foraminifers during the Pliocene at Sites 519, 521, 522, and 523. 
out the early and middle Pliocene for Globigerinoides sacculifer. If we assume that the $\delta_{\mathrm{w}}$ value of the middle Pliocene oceans was more positive by $0.4 \%$ than in the early Pliocene as a result of an increase in the global ice volume, the constant planktonic curve suggests a $2^{\circ} \mathrm{C}$ warming of South Atlantic surface water at a time of growing glaciers. This warming was obviously not restricted to equatorial surface water (Keigwin, 1979; and Vergnaud Grazzini, 1980); it extended as far as $30^{\circ} \mathrm{S}$.

Whereas the benthic oxygen isotopes mark the onset of the global cooling at $3.3 \mathrm{~m}$.y., the more negative carbon-isotope values of $P$. wuellerstorfi may signal an intensification of the AABW, or at least the presence of older and more corrosive bottom water. A horizontal section of $\delta^{13} \mathrm{C}$ in the present-day South Atlantic Ocean by Kroopnick (1980) shows a steady decrease of $\delta^{13} \mathrm{C}$ in the AABW toward the polar region. An intensification of the Antarctic bottom current in the middle Pliocene could have brought water with a more negative $\delta^{13} \mathrm{C}$ signature into the central South Atlantic; it may even have topped the Walvis Ridge and penetrated the Angola Basin.

\section{Late Pliocene and Early Pleistocene (2.5-1.1 Ma)}

A minor shift in the average oxygen-isotope composition of benthic foraminifers toward more positive values occurred 2.5 Ma. The difference in the average mean between middle and late Pliocene varies between $0.2 \%$ (Planulina wuellerstorfi) and 0.4\% (Nuttalides umbonifera). This second change in the Pliocene benthic record is associated with a distinct negative shift in the planktonic curve. If we assign the change in the benthic mean value to a further increase of global ice volume, the actual planktonic negative shift caused by a temperature change is even greater. A surface-water temperature increase of up to $3^{\circ} \mathrm{C}$ has to be postulated for the late Pliocene. The planktonic data suggest that during times of growing glaciers, low-latitude surface water on the one hand and growing glaciers in the polar regions on the other would have steepened the temperature gradient drastically during glaciations. An enhanced energy transfer from low latitudes to high latitudes in form of precipitation may have facilitated the rapid growth of late Pliocene glaciers (Adams, 1975). The observed isotopic changes $2.5 \mathrm{Ma}$ support the hypothesis that this was a time of major change in the characteristics of the global glaciation (Shackleton and Opdyke, 1977).

Additional evidence for a further deterioration in the Pliocene climate is given by the change in the facies pattern at Sites 522 and 523. The alternating light and dark nannofossil ooze layers were analyzed for their isotopic signature. The benthic oxygen-isotope signal of the dark layers is up to $1.2 \%$ more positive than the signals from the light-colored ooze. The dark ooze therefore was formed during glacial episodes.

During episodes of greater ice volume (dark layers), thermal gradients would be steeper in the ocean, with a consequent increase in divergence and intensity of upwelling. These phenomena would result in the bringing up of water more enriched in ${ }^{12} \mathrm{C}$. This enrichment is seen in the dark layers of Sites 522 and 523 (Fig. 8; Table 3). In addition, lowered sea level during glacial expan- sion would result in the introduction of more terrestrial organic material into the ocean, the effects of which are not wholly clear. According to one model (Shackleton, 1977), the introduction of large quantities of organic carbon into the ocean will enrich the entire water column in ${ }^{12} \mathrm{C}$. And, in fact, one sees such an enrichment in both benthic and planktonic tests at Sites 522 and 523 . However, the enrichment in benthic tests is greater than that of the planktonic tests by about $0.2 \%$. This disparity between surface and bottom ${ }^{12} \mathrm{C}$ enrichment was one of the lines of evidence used by Broecker (1981) to suggest that the entire water column was not affected equally and that the glacial ocean was significantly enriched in both $\mathrm{PO}_{4}$ and $\mathrm{NO}_{3}$.

In addition to an enrichment in ${ }^{12} \mathrm{C}$, the dark layers show evidence of increased carbonate dissolution. The causes of this phenomenon may be found in either or both of two processes. The increased dissolution in the dark layers may be the result of fluctuations in AABW activity. Today, the deep Angola Basin is filled from the north via the Romanche Fracture Zone with a mixture of water from the North Atlantic, Mediterranean, and the AABW. The carbon-isotope signature of the AABW in the Angola Basin is about $0.4 \%$ more positive than the carbon-isotope signature of the AABW south of the Angola Basin (Kroopnick, 1980). If, during the late Pliocene, AABW activity intensified to such an extent that the AABW rose and flowed over the Walvis Ridge into the Angola Basin during times of increased ice volume, the cold, $\mathrm{CO}_{2}$-rich, ${ }^{13} \mathrm{C}$-depleted AABW could produce both the observed isotopic signal (the average ${ }^{13} \mathrm{C}$ depletion from light to dark layers is $0.4 \%$ ) and increased carbonate undersaturation in the water column.

The second process that might account for part of the observed dissolution fluctuations is the interstitial dissolution of carbonate (Sayles, 1981; and Emerson and Bender, 1981). Acidic interstitial solutions are produced by the aerobic oxidation of the organic material that reaches the seafloor. During times of lowered sea level (greater ice volume; dark layers), more metabolic carbon enters the ocean and is reflected in the bottom sediments by both ${ }^{12} \mathrm{C}$ enrichment and increased carbonate dissolution.

If all the observed dissolution were due to fluctuations in AABW activity, one would expect sympathetic fluctuations in the proportion of $N$. umbonifera, because this parameter reflects changes in carbonate undersaturation in the water column (Fig. 10). To some extent there is a positive correlation between dissolution intensity and the proportion of $N$. umbonifera, especially at Site 523 (Table 3). At Site 522, although the direction of the trend is appropriate, there is too much scatter in the data to be more than $77 \%$ confident of there being a real difference between light and dark layers (Table 3). These observations suggest that both processes may be active (water column undersaturation due to the influx of AABW and interstitial removal of carbonate as a consequence of the carbon flux).

The difference observed here between glacial and interglacial periods in the late Pliocene-early Pleistocene resembles the magnitude of the changes observed in the late Pleistocene (Shackleton and Opdyke, 1976). The 
pattern of the planktonic oxygen-isotope record is surprising, however. The difference between the dark and light layers is smaller than in the benthic curve. Again, it seems that no significant low-latitude surface-water temperature changes were coupled with Pliocene glacialinterglacial cycles.

Estimates of sedimentation rates of dark/light nannofossil ooze cycles suggest that low-frequency climatic cycles on the order of 80,000 to $100,000 \mathrm{yr}$. had an important effect upon the paleoceanography and sedimentology. This observation, which is based on the limited number of analyzed cycles, does not support the conclusions of Pisias and Moore (1981), whose spectral analysis of an oxygen-isotope record from the equatorial Pacific suggests that low-frequency changes in the Pliocene oxygen-isotope record are not as important as in the late Pleistocene. However, a continuous high-resolution record of the Pliocene sequences at Sites 522 and 523 would be necessary to define the evolution of this pre-Quaternary climate more conclusively.

\section{CONCLUSIONS}

The benthic oxygen-isotope record allows the subdivision of the Pliocene into three periods with different climatic patterns. In the early Pliocene (5.2-3.3 Ma), low-amplitude climatic changes prevailed in a world that was less glaciated than during the Pleistocene. An interval of reduced Antarctic glaciers and relatively warm polar waters around 4.4 Ma is documented by low $\delta^{18} \mathrm{O}$ values in the benthic and planktonic foraminifers. Around 3.3 Ma, a $0.5 \%$ positive shift in the average $\delta^{18} \mathrm{O}$ composition of glacial and interglacial samples reflects a net increase in the global ice volume. The beginning of Northern Hemisphere glaciation and an extension of the Southern Hemisphere ice are responsible for this major shift in the benthic oxygen-isotope record. The middle Pliocene (3.3-2.5 Ma) is not only characterized by a more intensely glaciated world but also by more drastic ice-volume changes between glacial and interglacial times. Measured changes of up to $1.3 \%$ in the benthic oxygen-isotope record are comparable to Pleistocene differences between cold and warm periods. An additional major shift in the benthic ${ }^{18} \mathrm{O}$ record is dated as $2.5 \mathrm{~m} . \mathrm{y}$. Between 2.5 and $1.1 \mathrm{Ma}$ the cyclic climatic changes are documented not only in the isotope record but also in the lithology and dissolution record. Dark nannofossil ooze with a $\mathrm{CaCO}_{3}$ content between 60 and $70 \%$ was deposited in glacial periods, when the corrosive activity of the AABW and/or interstitial dissolution was intensified. A negative ${ }^{13} \mathrm{C}$ signal in the benthic foraminifers from the dark glacial sediments is construed as further evidence for periodic changes in the intensity of the late Pliocene-early Pleistocene bottom-water activity. The construed planktonic oxygen curves for the Pliocene are puzzling. No evidence is observed for a cooling of the surface water during times of growing glaciers.

We postulate that the surface water remained relatively warm during the deterioration of the Pliocene climate, even at $30^{\circ} \mathrm{S}$. These water masses provided moisture that was transferred to high latitudes and subsequently precipitated as snow on the growing polar ice caps.

\section{ACKNOWLEDGMENTS}

We are grateful to Dr. K. Perch-Nielsen (ETH-Z), Dr. J. P. Beckmann (ETH-Z), and Dr. C. Hemleben (Univ. Tübingen) for reviewing the manuscript and to Dr. K. J. Hsü (ETH-Z) for stimulating discussions. One of us (R. W.) wishes to thank Mary Bremer and Tom Loutit for fruitful and enlightening discussions about biochemical oceanography. The project was financially supported partly by Swiss Science Foundation Grant 5.521.330.787-9.

\section{REFERENCES}

Adams, D. P., 1975. Ice ages and the thermal equilibrium of the earth, II. Quat. Res., 5:161-171.

Berggren, W. A., 1972. Late Pliocene-Pleistocene glaciation. In Laughton, A. S., Berggren, W. A., et al., Init. Repts. DSDP, 12: Washington (U.S. Govt. Printing Office), 953-963.

Bremer, M. L. and Lohmann, G. P., 1982. Evidence for primary control of the distribution of certain Atlantic Ocean benthonic foraminifera by degree of carbonate saturation. Deep Sea Res., 29: 987-998.

Broecker, W. S., 1981. Glacial to interglacial changes in ocean and atmosphere chemistry. In Berger, A. (Ed.), Climatic Variations and Variability: Facts and Theories: Dordrecht (D. Reidel Publ. Co.), pp. 111-121.

Ciesielski, P. F., and Weaver, F. M., 1974. Early Pliocene temperature changes in the Antarctic seas. Geology, 2:511-515.

Craig, H., 1957. Isotopic standards for carbon and oxygen and correction factors for mass-spectrometric analysis of carbon dioxide. Geochim. Cosmochim. Acta, 12:133-149.

Deuser, W. G., Ross, E. H., Hemleben, C., and Spindler, M., 1981. Seasonal changes in species composition, numbers, mass, size and isotopic composition of planktonic foraminifera settling into the deep Sargasso Sea. Palaeogeogr. Palaeoclimatol. Palaeoecol., 33: 129-156.

Emerson, S., and Bender, M., 1981. Carbon fluxes at the sedimentwater interface of the deep sea: calcium carbonate preservation. $J$. Mar. Res., 39:139-162.

Emiliani, C., 1955. Pleistocene temperatures. J. Geology, 63:538-578.

Epstein, S., Buchsbaum, R., Loewenstam, H. A., and Urey, H. C., 1953. Revised carbonate-water isotopic temperature scale. Geol. Soc. Am. Bull., 64:1315-1326.

Kahn, M. I., and Williams, D. F., 1981. Oxygen and carbon isotopic composition of living planktonic foraminifera from the northeast Pacific Ocean. Palaeogeogr. Palaeoclimatol. Palaeoecol., 33:47-69.

Keigwin, L. D., 1979. Late Cenozoic stable isotope stratigraphy and paleoceanography of DSDP-sites from the east equatorial and central north Pacific Ocean. Earth Planet. Sci. Lett., 45:361-382.

Keigwin, L. D., and Thunnell, R. C., 1979. Middle Pliocene climatic change in the western Mediterranean from faunal and oxygen isotopic trends. Nature, 282:294-296.

Kroopnick, P., 1980. The distribution of ${ }^{13} \mathrm{C}$ in the Atlantic Ocean. Earth Planet. Sci. Lett., 49:469-484.

LaBrecque, J. L., Kent, D. V., and Cande, S. C., 1977. Revised magnetic polarity time scale for Late Cretaceous and Cenozoic time. Geology, 5:330-335.

Ledbetter, M. T., Williams, D. F., and Ellwood, B. B., 1978. Late Pliocene climate and southwest Atlantic abyssal circulation. Nature, 272:237-239.

Mankinen, E. A., and Dalrymple, G. B., 1979. Revised geomagnetic polarity time scale for interval 0-5 m.y.B.P. J. Geophys. Res., 84: 615-626.

Mercer, J. H., 1976. Glacial history of southernmost South America. Quat. Res., 6:125-166.

Pisias, N. G., and Moore, T. C., 1981. The evolution of Pleistocene climate: A time series approach. Earth Planet. Sci. Lett., 52: $450-458$.

Ruddiman, W. F., and Glover, L. K., 1972. Vertical mixing of icerafted volcanic ash in North Atlantic sediments. Geol. Soc. Am. Bull., 83:2817-2836.

Sayles, F. L., 1981. The composition and diagenesis of interstitial solutions-II. Fluxes and diagenesis at the water-sediment interface in the high latitude North and South Atlantic. Geochim. Cosmochim. Acta, 45:1061-1086.

Shackleton, N. J., 1977. Carbon-13 in Uvigerina: Tropical rainforest history and the Equatorial Pacific carbonate dissolution cycles. In 
Anderson, N. R., and Malahoff, A. (Eds.), The Fate of Fossil Fuel $\mathrm{CO}_{2}$ in the Oceans: New York (Plenum Press), pp. 401-427.

Shackleton, N. J., and Cita, M. B., 1979. Oxygen and carbon isotope stratigraphy of benthic foraminifera at Site 397: Detailed history of climatic change during the late Neogene. In von Rad, U., Ryan, W. B. F., et al., Init. Repts. DSDP, 47, Pt. 1: Washington (U.S. Govt. Printing Office), 433-447.

Shackleton, N. J., and Opdyke, N. D., 1976. Oxygen isotope and palaeomagnetic stratigraphy of Pacific core V28-239, late Pliocene to latest Pleistocene. Mem. Geol. Soc. Am., 145:449-464.

1977. Oxygen isotope and paleomagnetic evidence for Northern Hemisphere glaciation. Nature, 270:216-219.

Shackleton, N. J., and Vincent, E., 1978. Oxygen and carbon isotope studies in recent foraminifera from the southwest Indian Ocean. Mar. Micropaleontol., 3:1-13.

Vergnaud Grazzini, C., and Rabussier-Lointier, D., 1980. Compositions isotopiques de l'oxygène et du carbone des foraminifères ter- tiaires en Atlantique équatorial (Site $366 \mathrm{du}$ DSDP). Rev. Geol. Dyn. Geog. Phys., 22:63-74.

Vincent, E., Killingley, J. S., and Berger, W. H., 1981. Stable isotope composition of benthic foraminifera from the equatorial Pacific. Nature, 289:639-643.

Violanti, D., Premoli-Silva, I., Cita, M. B., Kersey, D. and Hsü, K. J., 1979. Quantitative characterization of carbonate dissolution facies of the Atlantic tertiary sediments. Riv. Ital. Paleontol., 85: 751-796.

Webb, P. N., 1972. Wright Fjord, Pliocene marine invasion of an Antarctic dry valley. Antarct. J. U.S., 7:225-232.

Williams, D. F., Sommer, M. A., and Bender, M. L., 1977. Carbon isotopic compositions of recent planktonic foraminifera of the Indian Ocean. Earth Planet. Sci. Lett. 36:391-403.

Woodruff, F., Savin, S., and Douglas, R. G., 1980. Biological fractionation of oxygen and carbon isotopes by recent benthic foraminifera. Mar. Micropaleontol. 5:3-11.

Date of Initial Receipt: July 29, 1982 